\title{
KNOWLEDGE, ATTITUDE AND ACCEPTANCE OF CONTRACEPTIVE METHODS AMONG WOMEN ATTENDING OPD OF COMMUNITY HEALTH CENTRE
}

\author{
Gitanjali Kapoor1, Dinesh Kumar²
}

${ }^{1}$ Assistant Surgeon, CHC Marh, J \& K Health Services, Jammu.

2Senior Resident, Department of Obstetrics and Gynaecology, SMGS Hospital, Jammu.

ABSTRACT
BACKGROUND
The aim of this study is to study the knowledge and attitude regarding contraceptive methods and practices of contraception
among women of reproductive age group.

\section{MATERIALS AND METHODS}

It was a hospital based cross-sectional study. The present study was undertaken among the 250 women of reproductive age group of 15 - 45 yrs. attending the community health centre in Marh block of Jammu district. A pre-designed, pre-tested and structured questionnaire was used in the study. The data collection technique was a personnel interview of the study subjects.

\section{RESULTS}

In our study, majority of women respondents (32.8\%) were in the age group of 25 - 29 yrs. Knowledge of any single method of contraception was found in 211 (84.4\%) respondents. Only $66 \%$ of the respondents showed a positive attitude towards contraception. Highest percentage of acceptance (51.21\%) of contraceptive methods was found in women in the age group of 40 45 yrs. The lowest percentage $(0 \%)$ of acceptance was found in the 15 - 19 years' age group. Contraception was less prevalent among Muslims (48.94\%) than Hindus (64.53\%). The contraceptive users increased as the level of education increased.

\section{CONCLUSION}

There is need to change the attitude of women regarding contraception, so as to increase the acceptance of contraception methods by initiating awareness programs at community level.

\section{KEYWORDS}

Knowledge, Attitude, Acceptance, Contraceptive Methods, Community Health Centre.

HOW TO CITE THIS ARTICLE: Kapoor G, Kumar D. Knowledge, attitude and acceptance of contraceptive methods among women attending OPD of community health centre. J. Evolution Med. Dent. Sci. 2017;6(28):2321-2324, DOI: 10.14260/Jemds/2017/499

\section{BACKGROUND}

India with current population of 1.33 billion represents $17.85 \%$ of the world's population. With the present population growth rate of $1.2 \%$, India is all set to take the numero uno position by 2030 with population of 1.53 billion.(1) Current population of $\mathrm{J}$ and $\mathrm{K}$ is 1.39 crores.(2) Fertility rate of India is 2.34 and that of $\mathrm{J}$ and $\mathrm{K}$ is $1.93 .(3)$ While 14 states have already achieved the replacement level including $\mathrm{J}$ and $\mathrm{K}$, contraceptive methods' use should be prevalent enough to maintain this level.(4) Family planning should be made accessible to every woman and man who needs it so that they can exercise their reproductive health rights, according to which everyone should be able to freely and responsibly decide how many children to have and when (that is children "By choice and not by chance").(5) Even though many programs are planned and implemented by Government of India and international organisations in the field of family planning with an idea of introducing various family planning methods to the couples in order to avoid unwanted pregnancies, there is development in the

Financial or Other, Competing Interest: None.

Submission 27-02-2017, Peer Review 22-03-2017,

Acceptance 30-03-2017, Published 06-04-2017.

Corresponding Author:

Dr. Gitanjali Kapoor,

Assistant Surgeon,

CHC Marh, J \& K Health Services.

E-mail: drdinesh1982@yahoo.com

DOI: $10.14260 /$ jemds $/ 2017 / 499$ acceptance of family planning methods but not to the extent that was targeted, and so the population continues to rise which is a major threat to India's endeavour to become a superpower.(6) That is why we came up with this study to assess the knowledge, attitude and acceptance of contraception among women of reproductive age in a rural area and to find out what are the various socio-demographic factors which are creating hurdles in the way of population control.

\section{MATERIALS AND METHODS}

A cross-sectional hospital based descriptive study was undertaken with 250 women of reproductive age 15 - 45 yrs. who attended the Gynae OPD of Community Health Centre, Marh for whatsoever causes. The study was carried out from September 2016 to December 2016.

A pre-tested and pre-structured questionnaire was used to collect information from the women respondents on the knowledge, attitude and acceptance of contraceptive methods. Verbal consent was taken before filling the questionnaire. Strict confidentiality of the data and privacy of the patients was maintained. Datas were entered in Microsoft Excel and analysed using open Epi Info for Windows version 7.2.1.

The Chi square test for proportions was used as the test of significance. Two-tailed $p$ value of less than 0.05 was considered significant. 


\section{RESULTS}

In our study age distribution among the respondents was: $3.2 \%, 20.4 \%, 32.8 \%, 17.2 \%, 10 \%$ and $16.4 \%$ in the age category of 15 - 19 yrs., 20 - 24 yrs., 25 - 29 yrs., 30 - 34 yrs., 35 - 39 yrs. and 40 - 45 yrs. respectively (Table 1).

Majority of women, i.e. 147 (58.8\%) belonged to joint family and 103 (41.2\%) belonged to nuclear family. Majority of women belonged to Hindu community, i.e. 203 (81.2\%) followed by Muslim community 47 (18.8\%). Majority of women were housewives $201(80.4 \%)$ followed by farmers 29 (11.6\%), self-employed 8 (3.2\%), Govt. Service 7 (2.8\%) and students 5 (2\%). Majority of women, i.e. 199 (79.6\%) were literate followed by 51 (20.4\%) illiterate. Majority of women, i.e. 72 (28.8\%) had family income less than Rs. 5000 followed by 62 (24.8\%) between Rs. 10 - 15000, 57 (22.8\%) between Rs. 5 - 10000, 39 (15.6\%) between Rs. 15 - 20000 and 20 (8\%) more than Rs. 20000 (Table 2).

Among literates, majority of women i.e. 62 (24.8\%) had secondary level of education followed by $43(17.2 \%)$ with higher secondary level of education, graduates 33 (13.2\%), middle $31(12.4 \%)$, primary $20(8 \%)$ and postgraduates 10 (4\%) (Table 3).

In our study, majority of the women i.e. $84.4 \%$ were knowing at least one method of contraception regardless of the educational level and socioeconomic status and only 39 (15.6\%) were ignorant about contraception. The most popular method among respondents was female sterilisation, i.e. $192(76.8 \%)$ followed by condoms 183 (73.2\%), oral pills 133 (53.2\%), IUCD 113 (45.2\%), natural methods like rhythm method 29 (11.6\%), abstinence 49 (19.6\%), withdrawal 53 (21.2\%), injectable contraceptives 9 (3.6\%), emergency contraception $9(3.6 \%)$ and lastly vasectomy $1(0.4 \%)$ (Table 4).

It is noticeable that $165(66 \%)$ women showed a positive attitude toward family planning and $53.2 \%$ husbands of the women counselled had approved contraceptives (Table 5).

In our study, the main source of knowledge about contraception was social circle 131 (62.09\%) followed by media 83 (39.34\%), health personal 71 (33.65\%) and education 43 (20.38\%) (Table 6).

About 104 (41.6\%) of respondents had used some contraceptive method and among them condom users were 32 (30.77\%), tubectomy 32 (30.77\%), oral pills $25(24.04 \%)$, natural methods 17 (16.35\%), IUCD 12 (11.54\%), injectables $3(2.88 \%)$ and emergency contraception 2 (1.92\%) (Table 7).

The highest percentage of acceptance was found in women in the age group of $40-45$, i.e. $58.54 \%$ followed by $58.14 \%$ in age group of $30-34$ yrs. Zero acceptance rate was found in age group of 15 - 19 yrs. The acceptance of contraceptive methods significantly increased with the increase of age $(\mathrm{p}<0.001)$ (Table 8).

Correlation between acceptance of contraceptive methods and education was not found significant $(p=0.14)$, because women with low education were following permanent method of sterilisation in good numbers (Table 9).

Majority of women (41.47\%) were practicing permanent method of sterilisation in the age group of $40-45$ yrs. and oral pills (20.9\%) in the age group of 30 - 34 yrs. (Table 10).

Family planning methods were less prevalent in Muslims (25.53\%) than Hindus (45.32\%). The difference was found significant $(\mathrm{p}<0.01)$ (Table 11$)$.
Table 12 shows the distribution of respondents according to view on male child and no. of children. When asked about whether there is must to have male child in family, $52.4 \%$ women responded in positive. The desire of male child was significantly high in women with low level of education $\left(\chi^{2}=\right.$ 56.4, $\mathrm{Df}=6, \mathrm{p}=<0.001$ ). When asked about ideal no. of children in a family, $62 \%$ responded two and $38 \%$ responded more than two. The desire of more no. of children was significantly high among women with low level of education $\left(\chi^{2}=106.3, \mathrm{Df}=6, \mathrm{p}=<0.001\right)$.

\begin{tabular}{|c|c|c|c|}
\hline Sl. No. & Age in Years & Number & Percentage \\
\hline 1 & $15-19$ & 8 & 3.2 \\
\hline 2 & $20-24$ & 51 & 20.4 \\
\hline 3 & $25-29$ & 82 & 32.8 \\
\hline 4 & $30-34$ & 43 & 17.2 \\
\hline 5 & $35-39$ & 25 & 10 \\
\hline 6 & $40-45$ & 41 & 16.4 \\
\hline \multicolumn{4}{|c|}{ Table 1. Showing Age Distribution of Respondents } \\
Interviewed \\
\hline
\end{tabular}

\begin{tabular}{|c|c|c|c|}
\hline \begin{tabular}{|c|} 
Socio- \\
demographic \\
Profile
\end{tabular} & Category & No. & Percentage \\
\hline \multirow[b]{2}{*}{ Religion } & Hindu & 203 & 81.2 \\
\hline & Muslim & 47 & 18.8 \\
\hline \multirow[b]{2}{*}{ Type of Family } & Nuclear & 103 & 41.2 \\
\hline & Joint & 147 & 58.8 \\
\hline \multirow[b]{2}{*}{ Education } & Illiterate & 51 & 20.4 \\
\hline & Literate & 199 & 79.6 \\
\hline \multirow{5}{*}{ Occupation } & House wives & 201 & 80.4 \\
\hline & Farmers & 29 & 11.6 \\
\hline & $\begin{array}{c}\text { Self- } \\
\text { Employed } \\
\end{array}$ & 8 & 3.2 \\
\hline & Govt. Service & 7 & 2.8 \\
\hline & Student & 5 & 2 \\
\hline \multirow{5}{*}{ Family Income } & $<5000$ & 72 & 28.8 \\
\hline & $5-10000$ & 57 & 22.8 \\
\hline & $\begin{array}{c}10000- \\
15000\end{array}$ & 62 & 24.8 \\
\hline & $\begin{array}{c}15000- \\
20000\end{array}$ & 39 & 15.6 \\
\hline & $>20000$ & 20 & 8 \\
\hline \multicolumn{4}{|c|}{$\begin{array}{c}\text { Table 2. Showing Distribution of Respondents } \\
\text { according to Residence }\end{array}$} \\
\hline
\end{tabular}

\begin{tabular}{|c|c|c|}
\hline Education Status & No. & Percentage \\
\hline Illiterate & 51 & 20.4 \\
\hline Primary & 20 & 8 \\
\hline Middle & 31 & 12.4 \\
\hline Secondary & 62 & 24.8 \\
\hline Higher Secondary & 43 & 17.2 \\
\hline Graduate & 33 & 13.2 \\
\hline Postgraduate & 10 & 4 \\
\hline Total & $\mathbf{2 5 0}$ & $\mathbf{1 0 0}$ \\
\hline Table 3. Showing Distribution of Respondents \\
according to Education \\
\hline
\end{tabular}

\begin{tabular}{|c|c|c|c|}
\hline & Category & $\begin{array}{c}\text { No. of } \\
\text { Respondents }\end{array}$ & Percentage \\
\hline $\begin{array}{c}\text { Awareness } \\
\text { about } \\
\text { contraceptive } \\
\text { methods }\end{array}$ & Yes & 211 & 84.4 \\
\cline { 2 - 4 } & No & 39 & 15.6 \\
\hline
\end{tabular}




\begin{tabular}{|c|c|c|c|}
\hline \multirow{8}{*}{$\begin{array}{c}\text { Awareness } \\
\text { about } \\
\text { different } \\
\text { contraceptive } \\
\text { methods }\end{array}$} & Condom & 183 & 73.2 \\
\hline & OC Pills & 133 & 53.2 \\
\hline & IUCD & 113 & 45.2 \\
\hline & Tubectomy & 192 & 76.8 \\
\hline & Injection & 9 & 3.6 \\
\hline & $\begin{array}{c}\text { Natural } \\
\text { Methods } \\
\text { Rhythm } \\
\text { Abstinence } \\
\text { Withdrawal } \\
\end{array}$ & $\begin{array}{l}29 \\
49 \\
53\end{array}$ & $\begin{array}{l}11.6 \\
19.6 \\
21.2\end{array}$ \\
\hline & Vasectomy & 1 & 0.4 \\
\hline & $\begin{array}{c}\text { Emergency } \\
\text { Contraception }\end{array}$ & 9 & 3.6 \\
\hline
\end{tabular}

\begin{tabular}{|c|c|c|}
\hline Approval & Number & \% \\
\hline By Women & 165 & 66 \\
\hline By Husbands & 133 & 53.2 \\
\hline \multicolumn{2}{|c|}{ Table 5. Attitude towards Family Planning } \\
\hline
\end{tabular}

\begin{tabular}{|c|c|c|}
\hline Source of Knowledge & Cases & $\%$ \\
\hline Media & 83 & 39.34 \\
\hline Health Personnel & 71 & 33.65 \\
\hline $\begin{array}{c}\text { Neighbour, friends and } \\
\text { relatives }\end{array}$ & 131 & 62.09 \\
\hline Education & 43 & 20.38 \\
\hline \multicolumn{3}{|c|}{$\begin{array}{l}\text { Table 6. Distribution of Respondents according to Source } \\
\text { of Knowledge of Contraceptives Methods }\end{array}$} \\
\hline
\end{tabular}

\begin{tabular}{|c|c|c|c|}
\hline & Category & No. of Respondent & $\%$ \\
\hline \multirow{2}{*}{$\begin{array}{c}\text { If used } \\
\text { contraceptive } \\
\text { method } \\
(n=250)\end{array}$} & Yes & 104 & 41.6 \\
\hline & No & 146 & 58.4 \\
\hline \multirow{7}{*}{$\begin{array}{l}\text { Methods ever } \\
\text { used } \\
(n=104)\end{array}$} & Condom & 32 & 30.77 \\
\hline & OC Pills & 25 & 24.04 \\
\hline & IUCD & 12 & 11.54 \\
\hline & Tubectomy & 32 & 30.77 \\
\hline & $\begin{array}{l}\text { Natural } \\
\text { methods }\end{array}$ & 17 & 16.35 \\
\hline & Injectables & 3 & 2.88 \\
\hline & $\begin{array}{c}\text { Emergency } \\
\text { contraception }\end{array}$ & 2 & 1.92 \\
\hline
\end{tabular}

\begin{tabular}{|c|c|c|c|c|c|c|}
\hline $\begin{array}{c}\text { In } \\
\text { Years }\end{array}$ & \multicolumn{2}{|c|}{ Cases } & $\begin{array}{c}\text { Contraceptive } \\
\text { Methods not } \\
\text { Accepting }\end{array}$ & $\begin{array}{c}\text { Contraceptive } \\
\text { Methods } \\
\text { Acceptance }\end{array}$ \\
\hline Age & No. & $\%$ & No. & $\%$ & No. & $\%$ \\
\hline $15-19$ & 8 & 3.2 & 8 & 100 & 0 & 0 \\
\hline $20-24$ & 51 & 20.4 & 46 & 90.2 & 5 & 9.80 \\
\hline $25-29$ & 82 & 32.8 & 46 & 56.1 & 36 & 43.90 \\
\hline $30-34$ & 43 & 17.2 & 18 & 41.86 & 25 & 58.14 \\
\hline $35-39$ & 25 & 10 & 11 & 44 & 14 & 56 \\
\hline $40-45$ & 41 & 16.4 & 17 & 41.46 & 24 & 58.54 \\
\hline Total & 250 & 100 & 146 & 58.4 & 104 & 41.6 \\
\hline \multicolumn{6}{|c|}{ Table 8. Correlation between Age of Women and } \\
\hline
\end{tabular}

$\chi^{2}=38.42, \mathrm{Df}=5, \mathrm{p}<0.001$

\begin{tabular}{|c|c|c|c|c|c|c|}
\hline \multirow{2}{*}{$\begin{array}{c}\text { Educa- } \\
\text { tional } \\
\text { Status }\end{array}$} & \multicolumn{2}{|c|}{ Cases } & \multicolumn{2}{c|}{$\begin{array}{c}\text { Contra- } \\
\text { ceptive } \\
\text { Methods not } \\
\text { Accepting }\end{array}$} & $\begin{array}{c}\text { Contra- } \\
\text { ceptive } \\
\text { Methods } \\
\text { Acceptance }\end{array}$ \\
\cline { 2 - 7 } & No. & $\%$ & No. & $\%$ & No. & $\%$ \\
\hline Illiterate & 51 & 20.4 & 26 & 50.98 & 25 & 49.02 \\
\hline Primary & 20 & 8 & 5 & 25 & 15 & 75 \\
\hline Middle & 31 & 12.4 & 18 & 58.06 & 13 & 41.94 \\
\hline Secondary & 62 & 24.8 & 29 & 41.86 & 33 & 53.23 \\
\hline High Sec. & 43 & 17.2 & 23 & 53.49 & 20 & 46.51 \\
\hline Graduate & 33 & 13.2 & 13 & 39.39 & 20 & 60.61 \\
\hline Post Grad & 10 & 4 & 2 & 20 & 8 & 80 \\
\hline Total & 250 & 100 & 146 & 58.4 & 104 & 41.6 \\
\hline \multicolumn{7}{|c|}{ Table 9. Correlation between Education and } \\
\multicolumn{7}{|c|}{ Contraceptive Methods Acceptance } \\
\hline
\end{tabular}

$\chi^{2}=9.654, \mathrm{Df}=6, \mathrm{p}=0.14$

\begin{tabular}{|c|c|c|c|c|c|c|c|}
\hline Age & NM & Condom & CuT & OCP & TT & Total & $\mathbf{\%}$ \\
\hline $15-19$ & 0 & 0 & 0 & 0 & 0 & 8 & 3.2 \\
\hline $20-24$ & 1 & 3 & 0 & 0 & 0 & 51 & 20.4 \\
\hline $25-29$ & 7 & 15 & 3 & 4 & 5 & 82 & 32.8 \\
\hline $30-34$ & 2 & 5 & 3 & 9 & 6 & 43 & 17.2 \\
\hline $35-39$ & 3 & 4 & 2 & 5 & 4 & 25 & 10 \\
\hline $40-45$ & 4 & 5 & 4 & 7 & 17 & 41 & 16.4 \\
\hline Total & $\mathbf{1 7}$ & $\mathbf{3 2}$ & $\mathbf{1 2}$ & $\mathbf{2 5}$ & $\mathbf{3 2}$ & $\mathbf{2 5 0}$ & $\mathbf{1 0 0}$ \\
\hline
\end{tabular}

Table 10. Correlation between Age of Respondents and different Contraceptive Methods Acceptance

\begin{tabular}{|c|c|c|c|c|}
\hline & Cases & $\mathbf{\%}$ & Acceptance & $\mathbf{\%}$ \\
\hline Hindu & 203 & 81.2 & 92 & 45.32 \\
\hline Muslim & 47 & 18.8 & 12 & 25.53 \\
\hline Total & $\mathbf{2 5 0}$ & $\mathbf{1 0 0}$ & $\mathbf{1 0 4}$ & \\
\hline \multicolumn{4}{|c|}{ Table 11. Correlation between Religion and } \\
Acceptance of Contraceptive Methods \\
\hline
\end{tabular}

$\chi^{2}=6.15, \mathrm{Df}=1, \mathrm{p}=0.01$

\begin{tabular}{|c|c|c|c|}
\hline & Category & $\begin{array}{c}\text { No. of } \\
\text { Respondents }\end{array}$ & Percentage \\
\hline $\begin{array}{c}\text { Male child is } \\
\text { must in a } \\
\text { family }\end{array}$ & Yes & 131 & 52.4 \\
\cline { 2 - 4 } & No & 119 & 47.6 \\
\hline $\begin{array}{c}\text { Ideal no. of } \\
\text { children in } \\
\text { family }\end{array}$ & 2 & 155 & 62 \\
\cline { 2 - 4 } & $>2$ & 95 & 38 \\
\hline \multicolumn{3}{|c|}{ Table 12. Distribution of Respondents according to } \\
view on Male Child and No. of Children \\
\hline
\end{tabular}

\section{DISCUSSION}

In our study, majority of women 82 (32.8\%) were in age group of 25 - 29 yrs. This is similar to study by Kaur A et al,(7) in which majority of respondents $51.5 \%$ were in the age group of 25 - 31 yrs. In our study, highest percentage of acceptance $(51.21 \%)$ of contraceptive methods was found in women in age group of $40-45$ yrs., which is similar to study by Lakshmi MM et al(6) in which maximum acceptance rate $(84.3 \%)$ was seen among 36 - 45 yrs. This is because most of the women at this age were using permanent method of sterilisation, i.e. tubectomy. Acceptance of family planning practices was less prevalent in Muslims (25.53\%) as compared to Hindus (45.32\%). The difference was found 
significant $(\mathrm{p}=0.01)$. This is similar to Mandloi $\mathrm{N}$ et al(8) who found prevalence of contraception (29.52\%) as compared to $(49.22 \%)$ in Hindus. This is because of religious belief of not using artificial methods of contraception. Correlation between contraceptive usage and women's education was not found significant $(\mathrm{p}=0.14)$, while other studies found significant association.(6,8) This is because in our study most of the women with low education were practicing permanent sterilisation, but they had not used any method for spacing with a result of high fertility rate.

In our study, majority of the women i.e. $84.4 \%$ were knowing at least one method of contraception regardless of the educational level and socioeconomic status and only 39 $(15.6 \%)$ were ignorant about contraception. This is similar to Srivastava $\mathrm{R}$ et al(9) and Mandloi $\mathrm{N}$ et al,(8) who found $82.2 \%$ and $98 \%$ women with knowledge of contraception respectively. This is because female sterilisation was known to even illiterates, although they were not knowing even a single method for spacing. In our study, the most common known method was tubectomy (76.8\%) followed by condoms (73.2\%), oral pills 133 (53.2\%) and IUCD 113 (45.2\%). This is similar to study by Srivastava $\mathrm{R}$ et $\mathrm{al}^{(9)}$ in which most commonly known methods were tubectomy (82.2\%), IUCD (61.2\%), oral pills (60.5\%) and condoms (53.7\%). Sunita TH et al(10) also found the most popular method as tubectomy in rural population. Sajid A et al(11) also found tubectomy the most commonly known method. In our study, the main source of knowledge about contraception was social circle $131(62.09 \%)$ followed by media 83 (39.34\%), health personal $71(33.65 \%)$ and education 43 (20.38\%), whereas studies by Mandloi $\mathrm{N}$ et $\mathrm{al}^{(8)}$ and Mustafa $\mathrm{R}$ et al(12) found media as the most common source of information. This showed that there is need to increase the involvement of health workers in spreading the message of contraception door to door and increase their confidence in them. In our study, 165 (66\%) women showed a positive attitude toward family planning and $53.2 \%$ husbands of the women counselled had approved contraceptives, whereas in study by Mustafa $\mathrm{R}$ et al $76 \%$ women showed a positive attitude toward family planning and $41 \%$ husbands of the women counselled had approved contraceptives; 52.2\% women showed desire for male child in our study, which is similar to study by Sunita TH et al(10) in which $45 \%$ women showed desire for male child; $38 \%$ women told ideal no. of children in a family should be $>2$, whereas in study by Sunita TH et al(10) this response was in $25 \%$ women.

\section{CONCLUSION}

This study reveals that there is still huge unmet need of contraception. Knowledge about temporary methods of contraception is lacking. Apart from this, want of male child, worries about side effects, religious beliefs, misconceptions are the other reasons for non-acceptance of contraception. So the need of the hour is to launch more programs at community level to combat the influence of various factors on contraception usage and to emphasise on the positive effects of the use of contraception. Misconceptions regarding the ill effects of the family planning methods should be removed. Vasectomy should be made popular as the permanent method of contraception, as it requires less manpower, easier, cheaper and more safe as compared to tubectomy.

\section{REFERENCES}

[1] India Guide: population of India: India's population in 2016 [Internet]. Available at www.indiaonlinepages.com/population/india_current _population.html. Cited 19 feb;2017.

[2] India Guide: population of India: India's population in 2016[Internet].Available at

www.indiaonlinepages.com/population/jammu

Kashmir_population.html.Cited 19 feb;2017.

[3] Estimates of fertility indicators 2013 [Internet]. Available at www.censusindia.gov.in/vital_statistics/SRS_Report_2 012/10_chap_3_2012.pdf. Cited 19 feb;2017.

[4] Annual report 2010-11. English- part 2, Ministry of health and family welfare-Govt. of India [Internet]. Available at www.mohfw.nic.in/showfile.php?lid=768. Cited 19 feb;2017.

[5] Renjhen P, Kumar A, Pattanshetty S, et al. A study on knowledge, attitude and practice of contraception among college students in Sikkim, India. J Turk Ger Gynecol Assoc 2010;11(2):78-81.

[6] Lakshmi MM, Neetha, Rai S. Contraceptive practices among reproductive age group of women in Justice K.S. Hegde Medical college hospital, Mangalore. Int J Reprod Contracept Obstet Gynecol 2013;2(1):39-46.

[7] Kaur A, Kaur B, Gupta A, et al. Assessment of knowledge and attitude regarding use of contraceptive methods among women at selected rural area, Ambala, Haryana, India. Int J Reprod Contracept Obstet Gynecol 2015;4(6):1907-13.

[8] Mandloi N, Verma K, Chaurasia S, et al. Knowledge, attitude and acceptance of contraceptive methods among women attending OPD of tertiary health center. J of Evolution of Med and Dent Sci 2015;4(77):1330921.

[9] Srivastava R, Srivastava DK, Jina R, et al. Contraceptive knowledge, attitude and practice (KAP Survey). J Obstet Gynecol India 2005;55(6):546-50.

[10] Sunita TH, Desai RM. Knowledge, attitude and practice of contraception among women attending a tertiary care hospital in India. Int J Reprod Contracept Obstet Gynecol 2013;2(2):172-6.

[11] Sajid A, Malik S. Knowledge, attitude and practice of contraception among multiparous women at Lady Aitchison Hospital, Lahore. Annals 2010;16(4):266-9.

[12] Mustafa R, Afreen U, Hashmi HA. Contraceptive Knowledge, attitude and practice among rural women. $\mathrm{J}$ of College of Physicians and Surgeons Pakistan 2008;18(9):542-54. 